\title{
A-Kinase Anchoring Protein 150 Mediates Transient Receptor Potential Family V Type 1 Sensitivity to Phosphatidylinositol-4,5-Bisphosphate
}

\author{
Nathaniel A. Jeske, ${ }^{1,2}$ Elaine D. Por, ${ }^{2}$ Sergei Belugin, ${ }^{3}$ Sraboni Chaudhury, ${ }^{1}$ Kelly A. Berg, ${ }^{2}$ Armen N. Akopian, ${ }^{3}$ \\ Michael A. Henry, ${ }^{3}$ and Ruben Gomez ${ }^{1}$ \\ Departments of ${ }^{1}$ Oral and Maxillofacial Surgery, ${ }^{2}$ Pharmacology, and ${ }^{3}$ Endodontics, The University of Texas Health Science Center, San Antonio, Texas 78229
}

\begin{abstract}
A-kinase anchoring protein 150 (AKAP150) is a scaffolding protein that controls protein kinase A- and C-mediated phosphorylation of the transient receptor potential family V type 1 (TRPV1), dictating receptor response to nociceptive stimuli. The phospholipid phosphatidylinositol4,5-bisphosphate $\left(\mathrm{PIP}_{2}\right)$ anchors AKAP150 to the plasma membrane in naive conditions and also affects TRPV1 activity. In the present study, we sought to determine whether the effects of PIP ${ }_{2}$ on TRPV1 are mediated through AKAP150. In trigeminal neurons and CHO cells, the manipulation of cellular PIP ${ }_{2}$ led to significant changes in the association of AKAP150 and TRPV1. Following PIP ${ }_{2}$ degradation, increased TRPV1: AKAP150 coimmunoprecipitation was observed, resulting in increased receptor response to capsaicin treatment. Phospholipase Cactivation in neurons isolated from AKAP150 ${ }^{-1-}$ animals indicated that $\mathrm{PIP}_{2}$-mediated inhibition of TRPV1 in the whole-cell environment requires expression of the scaffolding protein. Furthermore, the addition of PIP ${ }_{2}$ to neurons isolated from AKAP150 wild-type mice reduced PKA sensitization of TRPV1 compared with isolated neurons from AKAP150 ${ }^{-1-}$ mice. These findings suggest that PIP ${ }_{2}$ degradation increases AKAP150 association with TRPV1 in the whole-cell environment, leading to sensitization of the receptor to nociceptive stimuli.
\end{abstract}

\section{Introduction}

The transduction of intracellular signaling events is highly coordinated and often uses scaffolding proteins to control enzymatic modifications. A-kinase anchoring proteins (AKAPs) are a class of scaffolding proteins that were initially characterized to target the type II regulatory subunit of protein kinase A (PKA) to the membranes of cells and intracellular organelles (Carr et al., 1991; Dell'Acqua and Scott, 1997). Recently, AKAP79/150 (AKAP79 is the human ortholog, AKAP150 is the rodent ortholog) has been characterized to associate with other kinases and phosphatases, including PKC and protein phosphatase 2B (PP2B)/calcineurin (Coghlan et al., 1995; Klauck et al., 1996), as well as with several neuronal receptors and channels. Transient receptor potential family $\mathrm{V}$ type 1 (TRPV1) is a receptor that is regulated by its association with AKAP150 (Rathee et al., 2002; Jeske et al., 2008, 2009; Schnizler et al., 2008; Zhang et al., 2008). AKAP150 association with TRPV1 sensitizes nociceptive neurons in vivo (Por et al., 2010).

TRPV1 is an ionotropic, calcium-permeable channel that belongs to a larger family of ligand-gated TRP channels that re-

Received Jan. 3, 2011; revised April 28, 2011; accepted May 1, 2011.

Author contributions: N.A.J., A.A., and M.H. designed research; N.A.J., E.D.P., S.B., S.C., K.B., M.H., and R.G. performed research; N.A.J., E.D.P., K.B., A.A., and M.H. analyzed data; N.A.J. and E.D.P. wrote the paper.

This work was supported by NIH Grants R01 NS055835 (K.A.B.), R01 DE015576 (M.A.H.), R01 DE019311 (A.N.A.), and R01 NS061884 (N.A.J.). We thank David Julius and Mark Shapiro for kindly providing CDNA, and John Scott for providing CDNA and AKAP150 ${ }^{-\prime-}$ animals.

The authors declare no competing financial interests.

Correspondence should be addressed to Dr. Nathaniel A. Jeske, Department of Oral and Maxillofacial Surgery, MC 7908, UTHSCSA, 7703 Floyd Curl Drive, San Antonio, TX 78229-3900. E-mail: jeske@UTHSCSA.edu.

DOI:10.1523/JNEUROSCI.0020-11.2011

Copyright $\odot 2011$ the authors $\quad 0270-6474 / 11 / 318681-08 \$ 15.00 / 0$ spond to multiple environmental stimuli. TRPV1 is primarily expressed in primary afferent terminals of c-type nociceptive fibers (Kobayashi et al., 2005), and is activated following exposure to capsaicin and heat (temperature $>42^{\circ} \mathrm{C}$ ) (Caterina et al., 1997); protons, $\mathrm{pH}<5.9$ (Tominaga et al., 1998); lipids (Patwardhan et al., 2010); and certain cannabinoids (Ross et al., 2001; Price et al., 2004). In situations of injury or inflammation, circulating molecules and neuropeptides sensitize TRPV1 through the activation of signaling pathways that phosphorylate the receptor, including PKA (Bhave et al., 2002; Mohapatra and Nau, 2003) and PKC (Premkumar and Ahern, 2000; Bhave et al., 2003). Other post-translational modifications that affect TRPV1 activity include phosphorylation by CaMKII (Jung et al., 2004) as well as dephosphorylation by calcineurin/PP2B (Mohapatra and Nau, 2005). Although the outcomes of these enzymatic events on TRPV1 activity are generally well accepted, the effects of other post-translational modifications are less understood.

The acidic phospholipid phosphatidylinositol-4,5-bisphosphate $\left(\mathrm{PIP}_{2}\right)$ is reported to both sensitize and inhibit TRPV1. The exogenous application of $\mathrm{PIP}_{2}$ to excised patches activates TRPV1 (Stein et al., 2006), while phosphoinositide removal by poly-Lys application inhibits TRPV1 (Lukacs et al., 2007). In contrast, activation of TRPV1 following the application of capsaicin at low concentrations was sensitized by $\mathrm{PIP}_{2}$ degradation in a whole-cell environment (Lukacs et al., 2007). In agreement with this, Prescott and Julius (2003) presented a model of $\mathrm{PIP}_{2}$-mediated inhibition of TRPV1 activity, via direct association of the phosphoinositide with the $\mathrm{C}$ terminus of TRPV1. Together with other reports, $\mathrm{PIP}_{2}$ regulates TRPV1 activity through both direct and indirect mechanisms. In the present study, we provide evidentiary support for 
the hypothesis that $\mathrm{PIP}_{2}$ degradation drives AKAP150 association with TRPV1, positively modulating receptor/channel activity.

\section{Materials and Methods}

Tissue culture. All procedures using animals were approved by the Institutional Animal Care and Use Committee of The University of Texas Health Science Center at San Antonio and were conducted in accordance with policies for the ethical treatment of animals established by the National Institutes of Health (NIH). Trigeminal ganglia (TG) were cultured from male rats as previously described (Jeske et al., 2006). Cultures were maintained at $37^{\circ} \mathrm{C}, 5 \% \mathrm{CO}_{2}$, and grown for $5-7 \mathrm{~d}$ for coimmunoprecipitation experiments, and $1-2 \mathrm{~d}$ for calcium imaging and electrophysiology experiments. Chinese hamster ovary $(\mathrm{CHO})$ cells were used for heterologous expression of cDNA constructs. $\mathrm{CHO}$ cells were maintained in DMEM medium with $10 \%$ fetal bovine serum (Invitrogen ) and $1 \%$ penicillin/streptomycin (Invitrogen ). Cells were maintained at $37^{\circ} \mathrm{C}$, $5 \% \mathrm{CO}_{2}$ and transfected using Lipofectamine 2000 (Invitrogen) following the manufacturer's instructions.

Inositol phosphate accumulation. TG neurons (cultured and grown for $5 \mathrm{~d}$ in 24 well plates) were labeled with $2 \mu \mathrm{Ci} / \mathrm{ml}\left[{ }^{3} \mathrm{H}\right]$-myo-inositol $(25$ $\mathrm{Ci} / \mathrm{mmol}$; PerkinElmer) for $24 \mathrm{~h}$ at $37^{\circ} \mathrm{C}$ before experimentation. Bradykinin (BK)-mediated inositol phosphate (IP) accumulation was measured as described previously (Rowan et al., 2010). Data are expressed as mean ( \pm SEM) accumulation of total IPs (in disintegrations per minute).

Crude plasma membrane preparation. Cultured TG neurons and $\mathrm{CHO}$ cells were homogenized by 20 strokes in a Potter-Elvehjem homogenizer in hypotonic homogenization buffer (25 mM HEPES, 25 mM sucrose, 1.5 mм $\mathrm{MgCl}_{2}, 50 \mathrm{~mm} \mathrm{NaCl}, \mathrm{pH}$ 7.2) with peptidase/protease inhibitors aprotinin $(1 \mu \mathrm{g} / \mathrm{ml}$, Sigma-Aldrich), leupeptin (1 $\mu \mathrm{g} / \mathrm{ml}$, SigmaAldrich), pepstatin ( $1 \mu \mathrm{g} / \mathrm{ml}$, Sigma-Aldrich), and phenylmethylsulphonyl fluoride (PMSF) (100 nM; Sigma-Aldrich). Cell extract was incubated on ice for $15 \mathrm{~min}$ and then centrifuged at $1000 \times \mathrm{g}$ for $1 \mathrm{~min}$ at $4^{\circ} \mathrm{C}$ to remove nuclei and unlysed cells from homogenate. The resulting supernatant was centrifuged at $16,000 \times g$ for $30 \mathrm{~min}$ at $4^{\circ} \mathrm{C}$, separating cytosolic proteins from cell membrane proteins. The pellet (crude plasma membrane fraction) was then resuspended in $250 \mu \mathrm{l}$ of homogenization buffer containing $1 \%$ Triton (Fisher Scientific).

Immunoprecipitation and Western blot analysis. For each experimental condition, cells were treated with the indicated compounds and harvested for crude plasma membrane proteins, as described above. Protein quantification of crude plasma membrane homogenates was completed using the Bradford method (Bradford, 1976) as recommended by the manufacturer (Sigma-Aldrich). Following protein quantification, crude plasma membrane homogenates $(200 \mu \mathrm{g})$ were immunoprecipitated with $1 \mu \mathrm{g}$ of anti-TRPV1 (R-130, Santa Cruz Biotechnology). Next, immunoprecipitates were resolved via $12.5 \%$ SDS-polyacrylamide, and transferred to polyvinyl difluoride membrane (Millipore). Western blots were blocked in 5\% nonfat milk in Tris-buffered saline/Tween 20 (Fisher Scientific) and visualized using anti-AKAP150 (R-300, Santa Cruz Biotechnology) or anti-TRPV1 (R-130), followed by appropriate horseradish peroxidase-conjugated secondary antisera (GE Healthcare) and enhanced chemiluminescence detection following manufacturer's instructions (GE Healthcare). Western blotting was also performed on 25 $\mu \mathrm{g}$ aliquots of crude plasma membrane homogenates with AKAP150 antibody (R-300) and $\beta 1$-integrin-specific antibody (M-106, Santa Cruz Biotechnology). Densitometry measurements were determined using $\mathrm{NIH}$ Image 1.62, with reported pixel density $=[$ (band of interest density) - (lane background density)]/[(normalizing band) - (lane background density)]. Densitometry measurements were analyzed for significance by one-way ANOVA, with Bonferroni post hoc correction as needed $\left({ }^{* *} p<0.01,{ }^{* * *} p<0.001\right)$. IgG controls for antibodies used in these studies were performed previously (Jeske et al., 2009).

Confocal immunocytochemistry. Cultured TG neurons and CHO cells were grown on poly-D-lysine-coated coverslips (BD Biosciences) in normal media. Following indicated treatments (see Fig. 1, TG neurons) or transfection of exogenous cDNAs (see Fig. 2, CHO cells), coverslips were rinsed with PBS and fixed with $4 \%$ paraformaldehyde in phosphate buffer for $20 \mathrm{~min}$ at $25^{\circ} \mathrm{C}$. Following fixation, coverslips were rinsed twice with PBS, and incubated with a blocking solution consisting of $4 \%$ nor- mal goat serum (Sigma-Aldrich), 2\% bovine gamma globulin (SigmaAldrich), and $0.3 \%$ Triton X-100 (Fisher Scientific) in PBS for $60 \mathrm{~min}$ at $25^{\circ} \mathrm{C}$. TG coverslips were then incubated with antisera directed specifically toward AKAP150 (1:500; Millipore) and TRPV1 (1:2000; Neuromics) overnight at $25^{\circ} \mathrm{C}$. Coverslips were then rinsed three times in PBS and incubated with species-specific Alexa Fluor 488 and 633 goat secondary antibodies (1:100; Invitrogen) for $60 \mathrm{~min}$ at $25^{\circ} \mathrm{C}$. For green fluorescent protein (GFP) studies, $\mathrm{CHO}$ cells were processed as above, except that they were incubated with GFP antibody (1:250; Millipore) and Alexa Fluor 488 secondary antibody. Coverslips with cells were rinsed in PBS, then double-distilled $\mathrm{H}_{2} \mathrm{O}$, dried, and coverslipped with either Vectashield (TG cells) or Vectashield with DAPI (CHO cells; both from Vector Laboratories). Stained cells were evaluated with a Nikon Eclipse 90i C1si laser scanning confocal microscope and digital images were acquired with a $40 \times / 1.30$ numerical aperture (NA) oil-immersion objective. Control preparations were processed as described above, but lacked application of primary and/or secondary antibodies. Control preparations lacked specific immunofluorescence when viewed with the same laser gain settings used to obtain images of experimental preparations (data not shown).

$P K C$ activity assay. PKC kinase activity in primary TG cultures was determined following manufacturer's published protocols (CycLex PKC Super Family Kinase Assay Kit, MBL International Corporation). Absorbance values determined at $450 \mathrm{~nm}$ for each sample were normalized to individual protein quantifications for each sample (Bradford assay), and reported as PKC activity (normalized absorption at $450 \mathrm{~nm}$ ). Each sample was read in duplicate, and an $n$ value of 6 per treatment paradigm was used to determine statistical significance by one-way ANOVA with ad hoc Bonferroni correction.

Calcium imaging. TG neurons were isolated from male AKAP150 $0^{+/+}$ and AKAP $150^{-1-}$ mice, originally created and characterized in the laboratory of John D. Scott (University of Washington, Seattle, WA) (Tunquist et al., 2008). CHO cells were transfected as outlined above (see Tissue culture) with pEGFP-N1 (Clontech; to identify transfected cells) and cDNA vectors containing inserts corresponding to rat TRPV1 (generously provided by David Julius, UCSF, San Francisco, CA), rat AKAP150 wt (generously provided by John D. Scott, University of Washington, Seattle, WA), phosphoinositide-5-kinase (PI5-K), $\mathrm{PIP}_{2^{-}}$ phosphatase (PIP-2-P), and GFP-pleckstrin homology domain (GFPPHD) (generously provided by Mark S. Shapiro, University of Texas Health Science Center, San Antonio, San Antonio, TX). To measure intracellular $\left[\mathrm{Ca}^{2+}\right]$ levels, fura-2 AM (2 $\mu \mathrm{M}$; Invitrogen) was loaded for $30 \mathrm{~min}$ at $37^{\circ} \mathrm{C}$ into cells in the presence of $0.05 \%$ Pluronic (Calbiochem). Fluorescence was detected with a Nikon Eclipse TE 2000-U microscope fitted with a $20 \times / 0.8$ NA Fluor objective. Fluorescence images from 340 and $380 \mathrm{~nm}$ excitation wavelengths were collected and analyzed with MetaFluor Software (MetaMorph, Universal Imaging, a subsidiary of Molecular Devices). Net change in $\mathrm{Ca}^{2+}(\Delta \mathrm{F} 340 / 380)$ was calculated by subtracting basal F340/380 $\mathrm{Ca}^{2+}$ (mean value collected for a minimum of $60 \mathrm{~s}$ before agonist addition) from peak F340/380 $\mathrm{Ca}^{2+}$ achieved after exposure to capsaicin. For each transfection/treatment group, 23-95 cells were imaged (respectively indicated in each figure). Data were analyzed by one-way ANOVA analysis, with Bonferroni post hoc correction as needed $\left({ }^{*} p<0.05,{ }^{* *} p<0.01,{ }^{* * *} p<0.001\right)$.

Electrophysiology. TG neurons were isolated just as for the calcium imaging experiments. All recordings were made at $22-24^{\circ} \mathrm{C}$ from smallto-medium sized $(20-35 \mathrm{pF})$ neurons in a whole-cell voltage-clamp configuration at a holding potential $\left(\mathrm{V}_{\mathrm{h}}\right)$ of $-60 \mathrm{mV}$. Recordings and the following analysis were performed using an Axopatch 200B amplifier and pCLAMP9.0 software (Molecular Devices). Data were filtered at $0.5 \mathrm{kHz}$ and samples at $2 \mathrm{kHz}$. Borosilicate pipettes (Sutter) were polished to resistances of 3-5 MW in perforated patch pipette solution. If necessary, access resistance $\left(R_{s}\right)$ was compensated for by $40-80 \%$ to $8-10 \mathrm{MW}$.

All recordings are made in the presence of $2 \mathrm{mM} \mathrm{Ca}^{2+}$ in external solution. Standard external solution contained the following (in mM): $140 \mathrm{NaCl}, 5$ $\mathrm{KCl}, 2 \mathrm{CaCl}_{2}, 1 \mathrm{MgCl}_{2}, 10$ D-glucose, and 10 HEPES, pH 7.4. The pipette solution consisted of the following (in $\mathrm{mM}$ ): $140 \mathrm{KCl}, 4 \mathrm{NaCl}, 1 \mathrm{MgCl}_{2}, 1$ $\mathrm{CaCl}_{2}, 10$ EGTA, 10 HEPES, pH 7.3, 0.2 GTP-Na, and 2.5 ATP- $\mathrm{Mg}_{2}$ (Sigma). Vehicle (Veh) $(0.1 \% \mathrm{EtOH})$ or 8 -Br-cAMP $(8-\mathrm{Br})(10 \mu \mathrm{M})$ was 
A

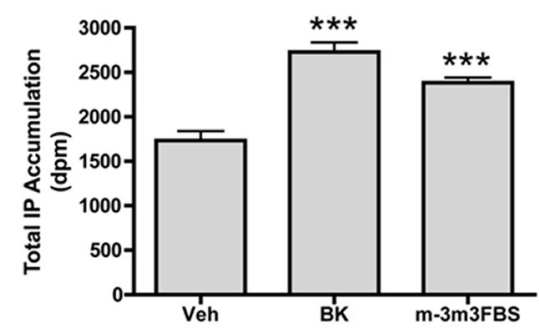

C
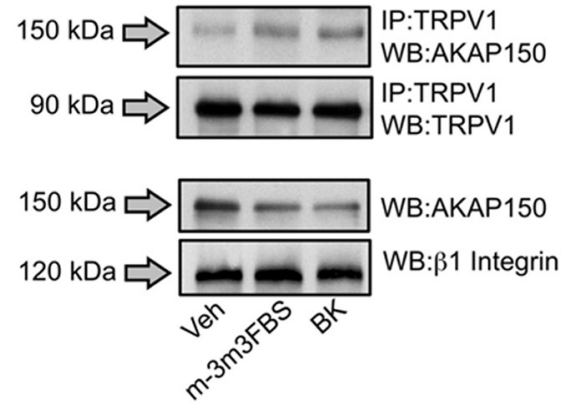

$\mathbf{E}$

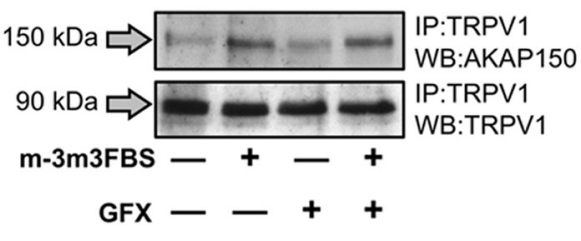

B

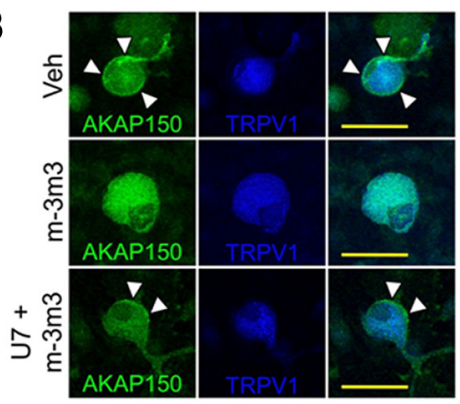

D

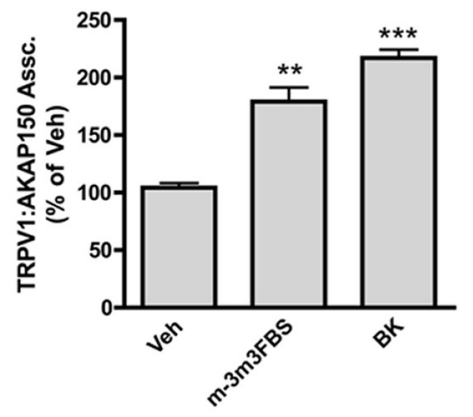

$\mathbf{F}$

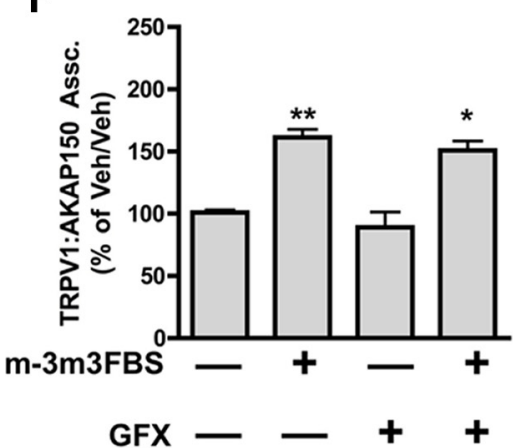

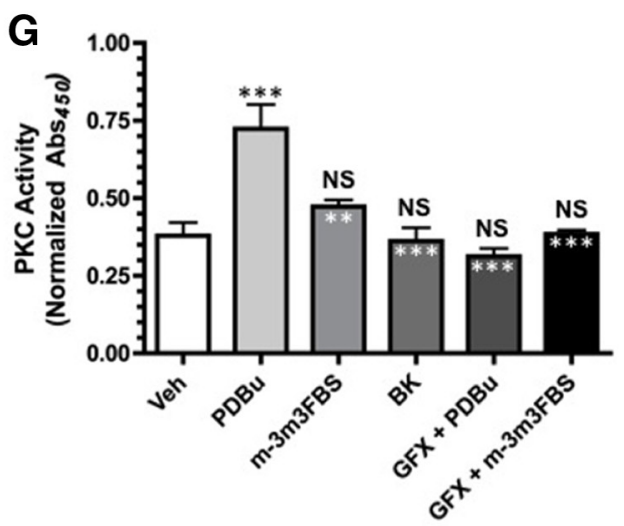

Figure 1. PLC activation increases TRPV1:AKAP150 association in TG neurons. $A$, Cultured TG neurons (24 well plates) were maintained in normal media and treated with Veh $(0.1 \% \mathrm{EtOH}), \mathrm{BK}(1 \mu \mathrm{M})$, or m-3m3FBS $(25 \mu \mathrm{m})$ for $5 \mathrm{~min}$ at $37^{\circ} \mathrm{C}$, upon which total IP accumulation was measured. Data are illustrated as the mean number of disintegrations per minute \pm SEM $(n=16$ wells/treatment). $\boldsymbol{B}$, Confocal immunocytochemistry of cultured TG neurons following treatment for 5 min at $37^{\circ} \mathrm{C}$ with Veh $(0.1 \%$ $\mathrm{EtOH}), \mathrm{m}-3 \mathrm{~m} 3 \mathrm{FBS}(\mathrm{m}-3 \mathrm{~m} 3,25 \mu \mathrm{m})$, or the PLC inhibitor U73122 (U7, $10 \mu \mathrm{m})$ and $\mathrm{m}-3 \mathrm{~m} 3 \mathrm{FBS}$. Arrowheads denote plasma membrane expression of AKAP150 (green) in TRPV1 (blue)-positive neurons. Results are representative of 10 separate images taken from 5 individual coverslips. Scale bar, $50 \mu \mathrm{m}$. C, Coimmunoprecipitates and crude plasma membrane homogenate samples of cultured TG neurons, serum starved for $18 \mathrm{~h}$, analyzed by Western blot following treatment for 5 min at $37^{\circ} \mathrm{C}$ with Veh $(0.1 \% \mathrm{Et} O \mathrm{H})$, $\mathrm{m}-3 \mathrm{~m} 3 \mathrm{FBS}(25 \mu \mathrm{m})$, or BK $(1 \mu \mathrm{M})$. Results are representative of four independent trials. D, Densitometric quantification of Western blot data shown in $C$, data reported as mean \pm SEM, $n=4$. E, Coimmunoprecipitates of cultured TG neurons, serum starved for $18 \mathrm{~h}$, analyzed by Western blot following treatment for $5 \mathrm{~min}$ at $37^{\circ} \mathrm{C}$ with Veh $(0.1 \% \mathrm{EtOH}), \mathrm{m}-3 \mathrm{~m} 3 \mathrm{FBS}(25 \mu \mathrm{M})$, and/or GFX (10 $\mu \mathrm{M})$. Results are representative of three independent trials. $F$, Densitometric quantification of Western blot data shown in $\boldsymbol{E}$; data are reported as mean $\pm \mathrm{SEM}, n=3$. Significance (compared with Veh treated) determined by one-way ANOVA with Bonferroni

applied for $5 \mathrm{~min}$ before capsaicin (CAP) application (100 nM). diC8-PIP 2 (50 $\mu \mathrm{M})$ (Li et al., 2005) was included in the pipette solution and dialyzed into neurons for $5 \mathrm{~min}$, during 8 - $\mathrm{Br}$ cAMP application, as indicated. Drugs were applied using a computer-controlled, pressuredriven eight channel system (ValveLink8; AutoMate Scientific). Data were analyzed by one-way ANOVA $\left({ }^{* * *} p<0.001\right)$

\section{Results}

Studies into the role of PLC in TRPV1 activation have yielded dichotomous conclusions. To determine whether AKAP150 is involved, we first sought to identify an activator of PLC in TG neurons. The PLC activator $\mathrm{m}-3 \mathrm{~m} 3 \mathrm{FBS}$ was previously characterized as an in vivo activator of PLC in a behavioral model of nociception (Schmidt et al., 2009). In non-serum-starved, cultured TG neurons, m-3m3FBS significantly increased PLC activation over vehicle treatment $(1733 \pm 105 \mathrm{dpm})$, as measured by IP accumulation (Fig. 1A) (one-way ANOVA, post hoc Bonferroni correction, $p<0.001$ ). Further, PLC activation following $\mathrm{m}-3 \mathrm{~m} 3 \mathrm{FBS}$ treatment $(2385 \pm 56 \mathrm{dpm})$ was similar to that following BK treatment $(2728 \pm 108$ $\mathrm{dpm}$ ) of TG neurons. Next, we probed for immunocytochemical AKAP150 expression profiles in TRPV1-positive TG neurons following vehicle and $\mathrm{m}-3 \mathrm{~m} 3 \mathrm{FBS}$ treatment (Fig. $1 B$ ). We found that AKAP150 is predominantly expressed at the plasma membrane, upon which m-3m3FBS-stimulated PLC activation releases the scaffolding protein from its plasma membrane anchorage, in agreement with Dell'Acqua et al. (1998). The PLC inhibitor U73122 partially inhibited the effects of m-3m3FBS, as evidenced by the focused expression of AKAP150 at the plasma membrane in cotreated neurons. Results from coimmunoprecipitation studies in Figure 1, $C$ and $D$, indicate that there is a significant increase in TRPV1 association with AKAP150 (TRPV1:AKAP150) following either m-3m3FBS $(179.1 \pm 12.3 \%, p<0.01)$ or BK treatment $(216.9 \pm 7.4 \%, p<0.001)$

$\leftarrow$

correction: ${ }^{*} p<0.05,{ }^{* *} p<0.01,{ }^{* * *} p<0.001$. G, PKC activity of cleared $T G$ culture lysates following treatment with Veh (0.1\% Et0H, $5 \mathrm{~min})$, PDBu (1 $\mu \mathrm{m}, 5 \mathrm{~min}), \mathrm{m}-3 \mathrm{~m} 3 \mathrm{FBS}$ ( 25 $\mu \mathrm{M}, 5 \mathrm{~min}), \mathrm{BK}(1 \mu \mathrm{M}, 5 \mathrm{~min}), \mathrm{GFX}(10 \mu \mathrm{m}, 5$ min pretreat)/ PDBu $(1 \mu \mathrm{M}, 5 \mathrm{~min})$, or GFX (10 $\mu \mathrm{m}, 5$ min pretreatment)/m$3 \mathrm{~m} 3 \mathrm{FBS}(25 \mu \mathrm{m}, 5 \mathrm{~min})$. All cultures not pretreated with GFX received vehicle $(0.1 \%$ DMSO) for 5 min before indicated treatment. Data reported as mean $\pm \mathrm{SEM}, n=6 /$ treatment. Significance (compared with Veh treated, indicated with black asterisks, and compared with PDBu treated, indicated with white asterisks) was determined by one-way ANOVA with Bonferroni correction: ${ }^{* *} p<0.01$, ${ }^{* * *} p<0.001$. NS, No significance. 
of cultured TG neurons over vehicle treatment $(104.3 \pm 3.8 \%$, one-way ANOVA, Bonferroni post hoc correction). Aliquots of crude plasma membrane homogenates also indicate a reduced expression of AKAP150 compared with $\beta 1$ integrin (plasma membrane marker), supporting the confocal immunocytochemical results in Figure $1 B$.

PLC activation is known to activate several PKC isozymes, including $\alpha, \beta 1, \beta 2$, and $\gamma$, through $\mathrm{IP}_{3}$-mediated $\mathrm{Ca}^{2+}$ release from intracellular stores and diacylglycerol generation. Previous results have demonstrated that $\mathrm{PKC}$ activation reduces AKAP150 expression in heterogeneous particulate fractions (Dell'Acqua et al., 1998), so we investigated the sensitivity of the PLC effect on PKC inhibition by GF109203X (GFX). As shown in Figure 1, E and $F$, PKC inhibition by GFX pretreatment before PLC activation by $\mathrm{m}-3 \mathrm{~m} 3 \mathrm{FBS}$ did not alter the increased association of AKAP150 and TRPV1 in crude plasma membrane homogenates of cultured TG neurons (161.4 $\pm 6.4 \%$ Veh/3-m3mFBS vs $150.9 \pm 7.5 \% \mathrm{GFX} / \mathrm{m}-3 \mathrm{~m} 3 \mathrm{FBS}$, one-way ANOVA, Bonferroni post hoc correction). Furthermore, neither m-3m3FBS nor bradykinin stimulated PKC activity to the same extent as the phorbol ester phorbol dibutyrate (PDBu) in TG cultures (Fig. 1G), suggesting that the PLC-mediated increase in AKAP150 association with TRPV1 in TG neurons is not dependent upon PKC activity.

Next, we used an expression system that influences endogenous levels of $\mathrm{PIP}_{2}$ through the transfection of $\mathrm{CHO}$ cells with cDNA transcripts encoding for the enzymes PI5-K (increases $\mathrm{PIP}_{2}$ ) and PIP-2-P (decreases $\mathrm{PIP}_{2}$ ) (Li et al., 2005). Using a GFP reporter that contains a pleckstrin homology domain (GFP$\mathrm{PHD}$ ), we monitored $\mathrm{PIP}_{2}$ content by observing GFP-PHD translocation from the plasma membrane to the cytosol following $\mathrm{PIP}_{2}$ hydrolysis (Hirose et al., 1999). As shown in Figure 2A, the coexpression of PI5-K results in the localized expression of the GFPPHD reporter to the plasma membrane of transfected cells, while PIP-2-P coexpression results in the translocation of the reporter to the cytosol, confirming expected results from the transfection of PI5-K and PIP-2-P in this model system. When cotransfected with TRPV1 and AKAP150 (alone, $100.7 \pm 2.3 \%$ ), PI5-K effectively decreases TRPV1 association with AKAP150 (56.4 $\pm 4.8 \%)$ in plasma membrane homogenates, while PIP-2-P increases association $(140.2 \pm 8.1 \%)$ (Fig. $2 B, C)$. Together, the manipulation of $\mathrm{PIP}_{2}$ content in the $\mathrm{CHO}$ model system through the coexpression of PI5-K or PIP-2-P has significant effects on TRPV1:AKAP150 association.

Prescott and Julius (2003) reported significant inhibitory effects of $\mathrm{PIP}_{2}$ on TRPV1 activity in receptor-expressing oocytes, suggesting that the phosphoinositide directly interacted with and affected TRPV1 activity (Prescott and Julius, 2003). Given the nature of AKAP150 movement following PLC activation (Fig. 1), and the modulatory properties that the scaffolding protein has on TRPV1 activity (Jeske et al., 2008, 2009; Schnizler et al., 2008; Zhang et al., 2008), we sought to determine whether the effects of $\mathrm{PIP}_{2}$ degradation on TRPV1 activity were more indirectly linked to AKAP150 association with TRPV1. In Figure 3, CHO cells were transfected with TRPV1 and either PI5-K or PIP-2-P, or TRPV1 and AKAP150 with either PI5-K or PIP-2-P, to measure capsaicin-stimulated TRPV1 activity by real-time calcium imaging following 8-Br-cAMP pretreatment. Neither PI5-K nor PIP2-P coexpression with TRPV1 alone yielded significant changes in TRPV1 activation by capsaicin with or without 8-Br-cAMP pretreatment (Fig. 3A, $C, E, G$ ). However, in cells expressing both TRPV1 and AKAP150, PIP-2-P coexpression yielded significantly greater responses in both capsaicin and 8-Br-cAMPsensitized capsaicin-treated cells over those coexpressing TRPV1
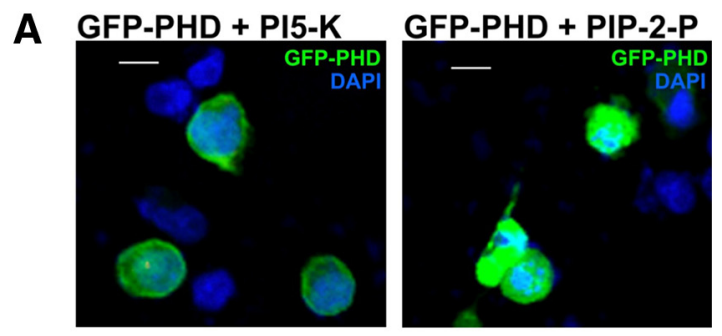

B
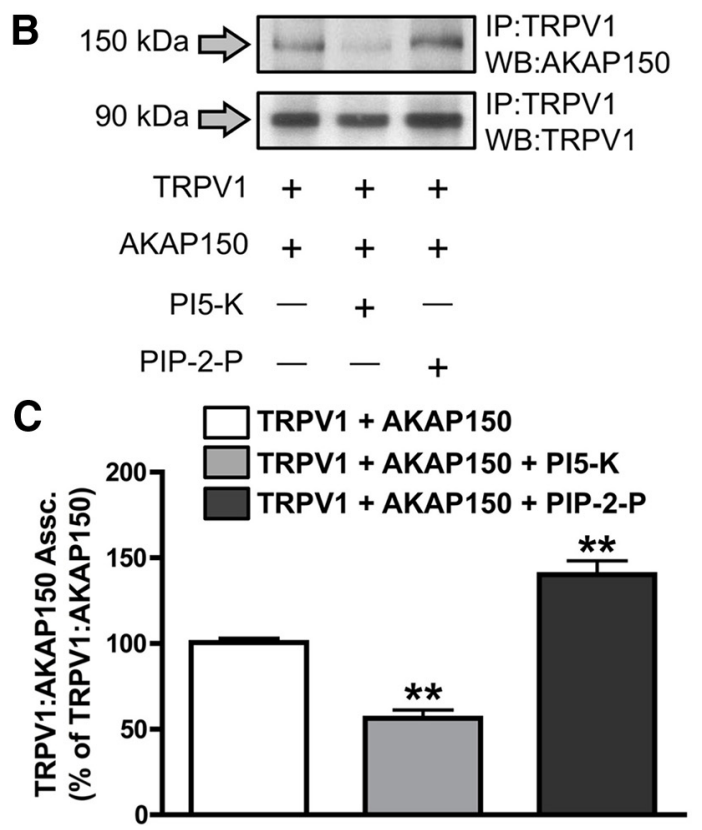

Figure 2. $\mathrm{PI}(4,5) \mathrm{P}_{2}$ modulation affects TRPV1:AKAP150 association. $\boldsymbol{A}$, Confocal immunocytochemistry of $\mathrm{CHO}$ cells transfected with the GFP-PHD reporter (green) and PI5-K, or GFP-PHD and PIP-2-P. DAPI (neuronal marker, blue) was used to identify individual cells, and results are representative of 10 separate images taken from three individual sets of coverslips. Scale bar, 10 $\mu \mathrm{m} . \boldsymbol{B}$, Coimmunoprecipitates from crude plasma membrane homogenates taken from cells transfected with the indicated cDNAs. Results are representative of five independent trials. $\boldsymbol{C}$, Densitometric quantification of Western blot data shown in $\boldsymbol{B}$; data reported as mean $\pm \mathrm{SEM}$, $n=5$. Significance was determined by one-way ANOVA, with Bonferroni correction: ${ }^{* *} p<$ 0.01 .

and AKAP150 alone (Fig. $3 B, F, H$ ). Furthermore, PI5-K coexpression was unable to significantly affect 8-Br-cAMP-sensitized capsaicin responses in TRPV1- and AKAP150-expressing cells over those expressing only TRPV1 and AKAP150 alone (Fig. $3 B, D, H)$. These results indicate that TRPV1 modulation by $\mathrm{PIP}_{2}$ requires AKAP150.

We next wanted to confirm the results from our heterologous CHO model system using cultured TG neurons isolated from AKAP $150^{+/+}$and AKAP $150^{-/-}$mice. As shown in Figure $4 A$, the pretreatment of cultured AKAP $150^{+/+}$neurons with the PLC activator $\mathrm{m}-3 \mathrm{~m} 3 \mathrm{FBS}$ resulted in the sensitization of CAPinduced calcium accumulation, similar to the CAP response following pretreatment with the PKA activator $8-\mathrm{Br}$. To discern whether the PLC effect was solely due to AKAP150, we repeated the experiment in AKAP $150^{-/-}$neurons, upon which both PLCand PKA-directed sensitization of CAP-mediated calcium accumulation was abolished (Fig. $4 B$ ). The quantified results of these studies, as illustrated in Figure $4 C$, indicate that PLC-mediated sensitization of TRPV1 activity relies on functional AKAP150 scaffolding protein expression to the same extent as PKAmediated sensitization of TRPV1 relies on AKAP150 (Jeske et al., 2008; Schnizler et al., 2008). 

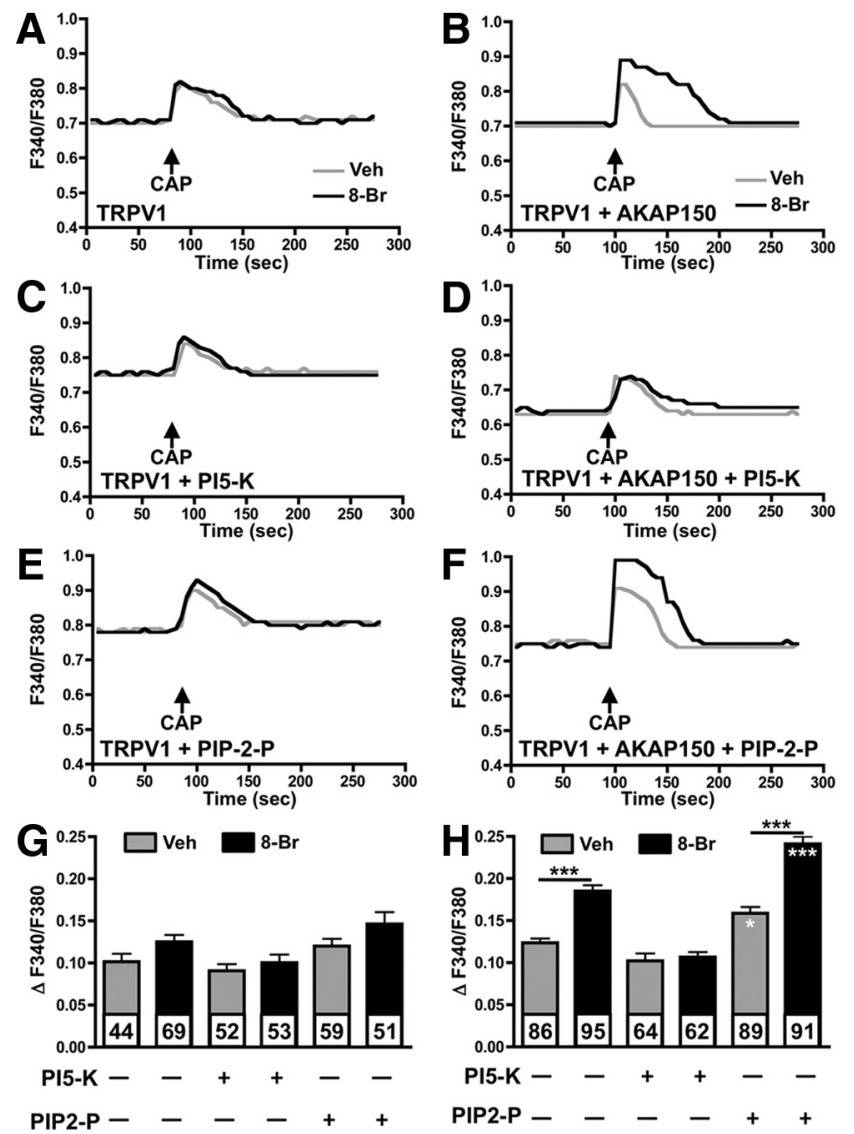

Figure 3. AKAP150 expression is required for $\mathrm{PI}(4,5) \mathrm{P}_{2}$ to modulate TRPV1 activity. $\boldsymbol{A}-\boldsymbol{F}$, CHO cells were transiently transfected with CDNAs corresponding to TRPV1 (A), TRPV1 and PI5-K (C), TRPV1 and PIP-2-P (E), TRPV1 and AKAP150 (B), TRPV1, AKAP150 and PI5-K (D), or TRPV1, AKAP150, and PIP-2-P $(\boldsymbol{F})$, with sample calcium imaging curves following a capsaicin $(50 \mathrm{~nm}$, $30 \mathrm{~s}$, designated by arrow) challenge following $\mathrm{Veh}(0.1 \% \mathrm{EtOH})$ or $8-\mathrm{Br}(10 \mu \mathrm{M})$ pretreatment for 30 s. Arrows denote CAP application. $\boldsymbol{G}$, Data represented in $\boldsymbol{A}, \boldsymbol{C}$, and $\boldsymbol{E}$ are quantified; $n$ values are shown for each treatment/transfection paradigm. $\boldsymbol{H}$, Data represented in $\boldsymbol{B}, \boldsymbol{D}$, and $\boldsymbol{F}$ are quantified, with data reported as mean $\pm \mathrm{SEM} ; n$ values are shown for each treatment/ transfection paradigm. Black asterisks indicate significance between indicated groups; white asterisks indicate significance between Veh or 8-Br groups in TRPV1- and AKAP150-transfected cells, and TRPV1, AKAP150, and PIP-2-P cotransfected cells, respectively. Significance was determined by one-way ANOVA with Bonferroni correction: ${ }^{*} p<0.05,{ }^{* * *} p<0.001$.

Whole-cell electrophysiology was used to measure changes in TRPV1 activity at the plasma membrane following 5 min dialysis of the water-soluble phosphoinositide diC8-PIP 2 into cells by including it in the pipette solution ( $\mathrm{Li}$ et al., 2005). TG neurons were cultured and treated with the PKA activator $8-\mathrm{Br}(10 \mu \mathrm{M})$ alone or with diC8-PIP $2\left(\mathrm{PIP}_{2}, 50 \mu \mathrm{M}\right)$ and 8-Br-cAMP for $5 \mathrm{~min}$ before capsaicin application. In Figure $5, \mathrm{PIP}_{2}$ application blocked 8-Br-mediated sensitization of TRPV1 in neurons isolated from AKAP $150^{+/+}$mice, but had no effect in neurons cultured from AKAP $150^{-1-}$ mice.

In Figure 6, we used inhibitors of PKA (H-89) and PKC (GFX) to determine whether PLC stimulation following m-3m3FBS led to additive or superadditive effects of the kinases upon TRPV1. In Figure $6, A$ and $B$, the sensitizing effect of 8 -Br on TRPV1 activity was significantly increased with the cotreatment of m-3m3FBS. PKA inhibition by $\mathrm{H}-89$ completely blocked 8 -Br sensitization of TRPV1 and also reduced TRPV1 sensitization by m-3m3FBS. However, since this reduction was not complete abrogation, we determined that either PLC activation by m-3m3FBS could be indirectly activating PKC (Cesare et al., 1999) to phosphorylate
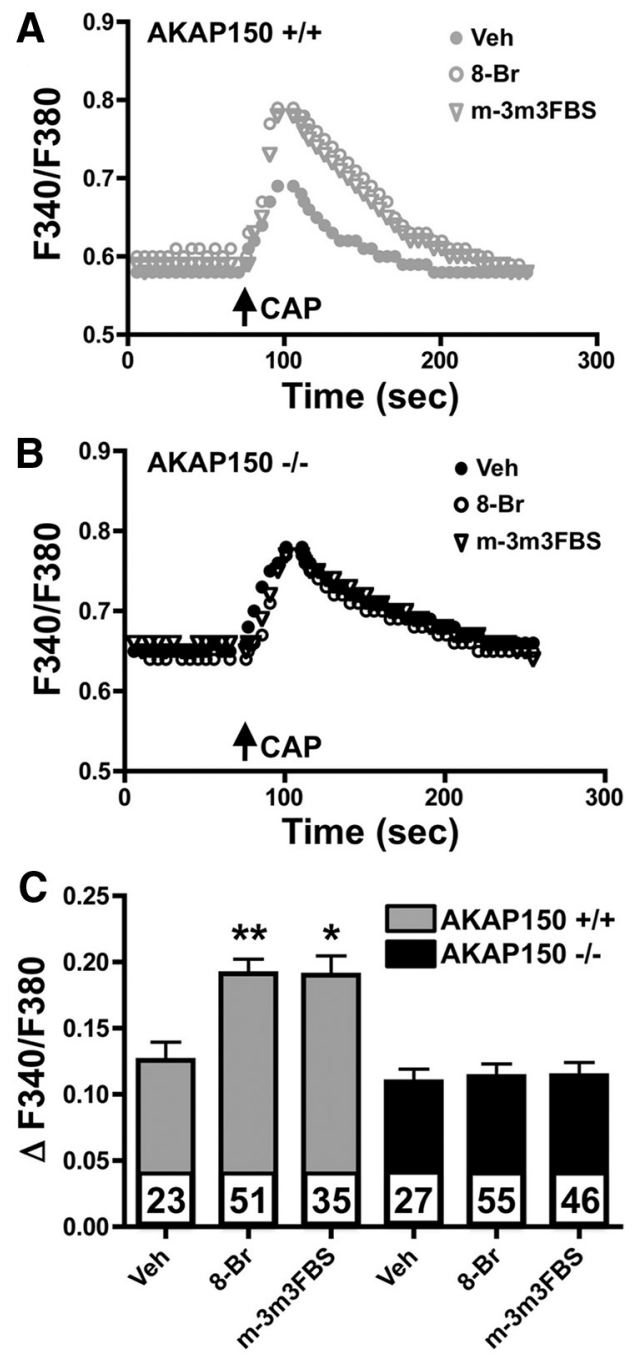

Figure 4. Genetic ablation of AKAP150 blocks ability of PLC to regulate TRPV1 activity. $\boldsymbol{A}$, Sample calcium imaging curves upon a capsaicin $(50 \mathrm{~nm}, 30 \mathrm{~s}$, designated by arrow) challenge in cultured TG neurons isolated from AKAP150 ${ }^{+/+}$mice, following pretreatment with Veh $(0.1 \%$ EtoH, closed gray circle), 8-Br (10 $\mu \mathrm{m}$, open gray circle), or m-3m3FBS (25 $\mu \mathrm{m}$, open gray triangle) for 30 s. $B$, Sample capsaicin curves of cultured TG neurons isolated from AKAP $150^{-1-}$ mice, following pretreatment with Veh $(0.1 \%$ EtOH, closed black circle), $8-\mathrm{Br}$ (10 $\mu \mathrm{m}$, open black circle), or m-3m3FBS ( $25 \mu \mathrm{m}$, open black triangle). Arrows denote (AP application. C, Quantification of calcium imaging measurements taken from those represented in $\boldsymbol{A}$ and $\boldsymbol{B}$; data are reported as mean \pm SEM, $n$ values are shown for each treatment/genotype paradigm. Significance of Veh-treated responses to capsaicin was determined by one-way ANOVA with Bonferroni correction: ${ }^{*} p<0.05,{ }^{* *} p<0.01$.

and sensitize TRPV1, or the PLC-mediated increase in AKAP150 association with TRPV1 could direct increased PKC phosphorylation and sensitization of TRPV1 (Jeske et al., 2009). Therefore, we repeated the experiment with PDBu (PKC activator) and GFX (PKC inhibitor). PKC inhibition by GFX reduced $\mathrm{m}-3 \mathrm{~m} 3 \mathrm{FBS}-$ induced sensitization of TRPV1 when compared with Veh/m$3 \mathrm{~m} 3 \mathrm{FBS}$; however, it did not completely block the effect of PLC activation (Fig. 6C,D). Together, results indicate that PLC activation allows for increased PKC- and PKA-mediated sensitization of TRPV1, likely through increased association of AKAP150 with TRPV1.

\section{Discussion}

The role of the scaffolding protein AKAP150 in TRPV1 phosphorylation has been characterized in multiple models (Rathee et 

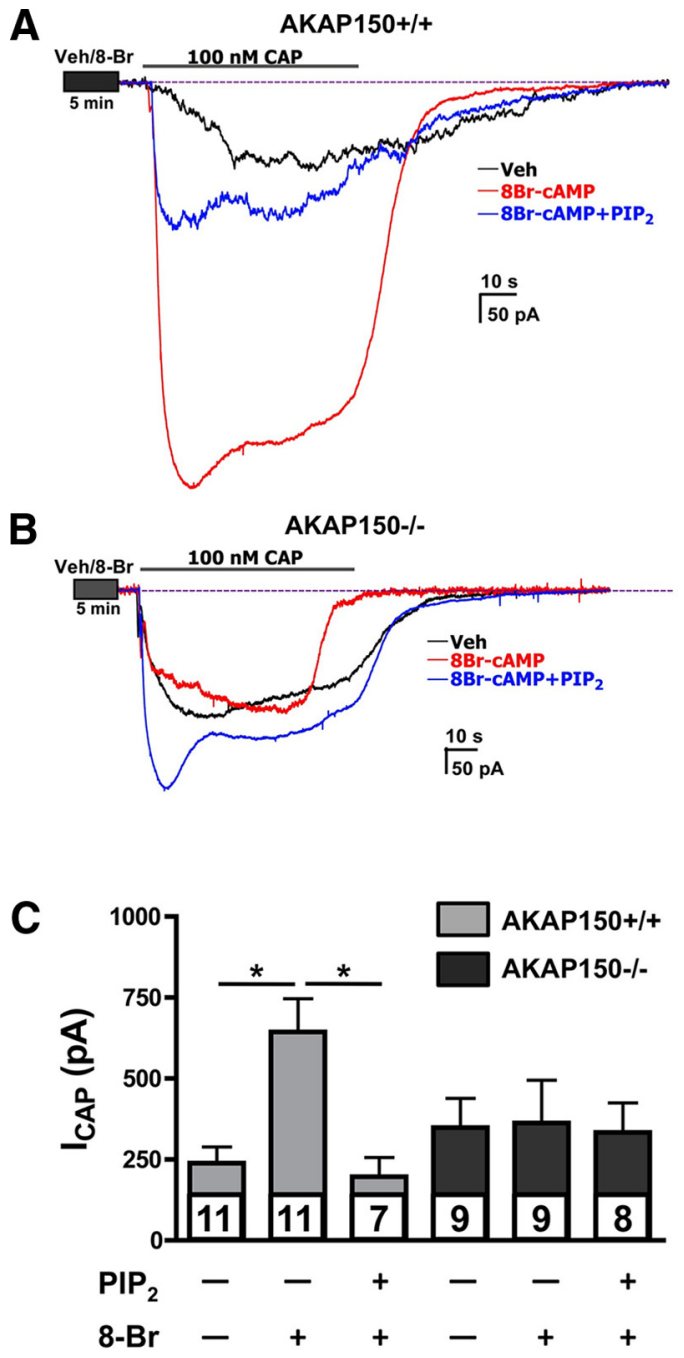

Figure 5. PIP 2 reduces PKA sensitization of TRPV1 in AKAP150 ${ }^{+/+}$, but not AKAP $150^{-/-}$neurons. TG neurons were isolated and cultured from AKAP150 ${ }^{+/+}$and AKAP150 ${ }^{-/-}$mice, and were treated with either 8-Br $(10 \mu \mathrm{M})$ or 8-Br and dic8-PIP $\left(\mathrm{PIP}_{2}, 50 \mu \mathrm{M}\right)$ for 5 min before CAP application $(100 \mathrm{~nm}) . A$, Sample traces of inward currents taken from AKAP $150^{+/+}$neurons following indicated treatments. $\boldsymbol{B}$, Sample traces of inward currents taken from AKAP150 ${ }^{-1-}$ neurons following indicated treatments. C, Quantification of cumulative currents induced by $C A P\left(I_{C A P}\right)$; data are reported as mean $\pm S E M, n$ values are shown for each treatment/genotype paradigm. Significance was determined by one-way ANOVA with Bonferroni correction: ${ }^{*} p<0.05$.

al., 2002; Jeske et al., 2008, 2009; Schnizler et al., 2008; Zhang et al., 2008). However, the potential role of AKAP150 in the posttranslational regulation of TRPV1 by PIP ${ }_{2}$ has not been studied. Employing both immortalized $\mathrm{CHO}$ cell cultures and primary TG neuronal cultures, experimental results indicate that PLC activation releases $\mathrm{PIP}_{2}$-anchored AKAP150 to associate with TRPV1 and thereby modulate its phosphorylation and sensitization by PKA and PKC. Experimental results indicate that $\mathrm{PIP}_{2}-$ directed modulation of TRPV1 activity requires AKAP150 coexpression in both heterologous cells and neuronal cultures. Additionally, the exogenous application of $\mathrm{PIP}_{2}$ reduces CAP sensitivity only in TG neurons isolated from AKAP $150^{+/+}$mice, and not from AKAP $150^{-1-}$ mice. Together, our results indicate that PLC-mediated sensitization of TRPV1 activity is AKAP150 dependent, as depicted in Figure 7.

Phosphoinositides such as $\mathrm{PIP}_{2}$ regulate numerous ion channels, including multiple isoforms of inwardly rectifying potassium channels (for review, see Logothetis et al., 2010), P2X 2/3

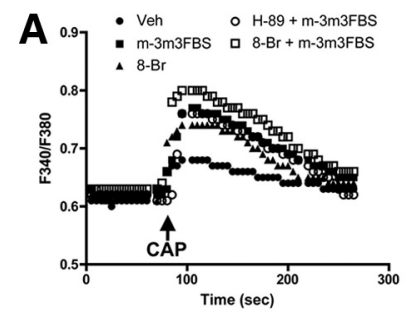

B
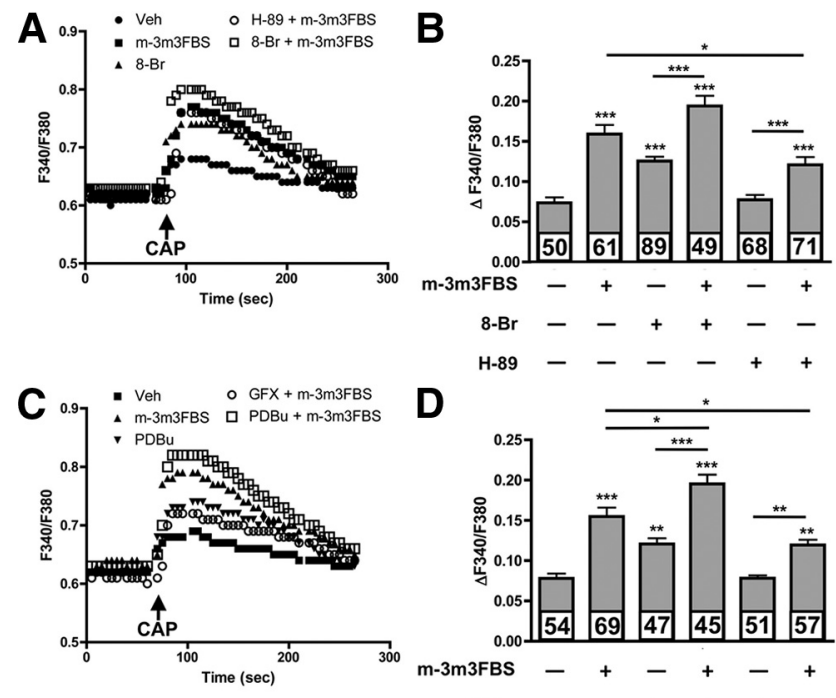

D
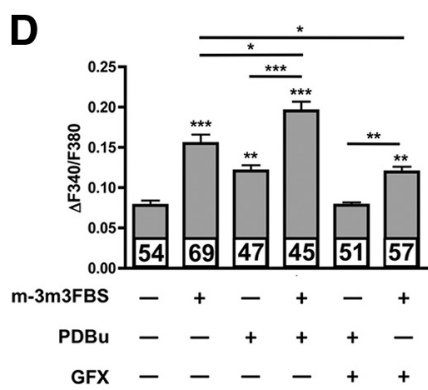

Figure 6. PKA and PKC increase PLC effects on TRPV1 activity. TG neurons were isolated and cultured, serum starved for $18 \mathrm{~h}$, and treated with $\mathrm{m}-3 \mathrm{~m} 3 \mathrm{FBS}(25 \mu \mathrm{m}), 8-\mathrm{Br}(10 \mu \mathrm{m}), \mathrm{H}-89(20 \mu \mathrm{m})$, PDBu $(1 \mu \mathrm{M})$, and/or GFX (10 $\mu \mathrm{m})$, for 5 min each. $A$, Sample calcium imaging curves following capsaicin application ( $50 \mathrm{~nm}, 30 \mathrm{~s}$, designated by arrow) pretreated with $\mathrm{m}-3 \mathrm{~m} 3 \mathrm{FBS}, 8-\mathrm{Br}$, and/or H-89. $\boldsymbol{B}$, Quantification of calcium imaging measurements represented in $\boldsymbol{A}$; data are reported as mean $\pm S E M, n$ values are shown for each treatment paradigm. Significance determined by one-way ANOVA with Bonferroni correction: ${ }^{* *} p<0.005$. Significance to Veh/Veh/Veh-treated responses shown by asterisks above bars; all other significance is depicted as shown. C, Sample calcium imaging curves following capsaicin (designated by arrow) pretreated with $\mathrm{m}-3 \mathrm{~m} 3 \mathrm{FBS}, \mathrm{PDBu}$, and/or GFX. D, Quantification of calcium imaging measurements represented in $\boldsymbol{C}$; data are reported as mean \pm SEM, $n$ values are shown for each treatment paradigm. Significance was determined by one-way ANOVA with Bonferroni correction: ${ }^{*} p<0.05,{ }^{* *} p<0.01,{ }^{* * *} p<0.005$. Significance of Veh/Veh/ Veh-treated responses is shown by asterisks above bars; all other significance is depicted as shown.

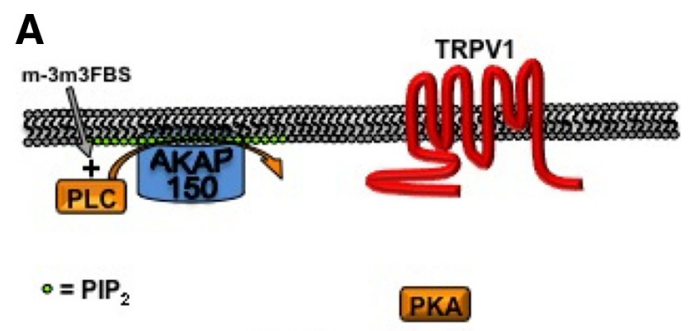

PKC

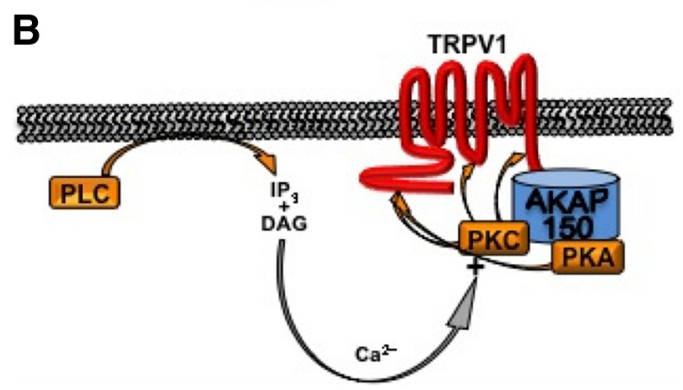

Figure 7. Model of PLC-stimulated AKAP150 association with TRPV1.A, In nascentcells, AKAP150 is localized to $\mathrm{PIP}_{2}$-rich areas of the plasma membrane. When PLC is activated, $\mathrm{PIP}_{2}$ is degraded, releasing AKAP150 from its plasma membrane anchorage, from where it can associate with target substrate proteins, including TRPV1. B, Following association with TRPV1, AKAP150 then scaffolds PKC and PKC to phosphorylate TRPV1, effectively sensitizing the receptor. 
(Mo et al., 2009), and the epithelial sodium channel (Kunzelmann et al., 2005). For TRPV1, the effect of $\mathrm{PIP}_{2}$ on receptor/ channel activity is less clear, in that the phosphoinositide demonstrates direct and indirect effects on increasing and/or decreasing channel activity. Studies by Prescott and Julius (2003) detail an inhibitory role for $\mathrm{PIP}_{2}$ on TRPV1 activation by $\mathrm{pH}$ and heat through the direct association of the phosphoinositide with a modulatory binding motif in the $\mathrm{C}$ terminus. However, other groups have demonstrated sensitization of TRPV1 activity following the exposure of excised patches to $\mathrm{PIP}_{2}$ (Stein et al., 2006; Lukacs et al., 2007). Liu et al. (2005) reported that the recovery of TRPV1 from pharmacological desensitization is prevented by $\mathrm{PIP}_{2}$ depletion, although only in whole-cell preparations. In agreement with this, others have also reported an activating effect of $\mathrm{PIP}_{2}$ binding to the $\mathrm{C}$-terminal end of TRPV1 in response to heat activation when chimerically linked to TRPM8 (Brauchi et al., 2007). Yet, the apparent ambiguity may simply be due to the lack of knowledge on indirect signaling events that may extend from PIP $_{2}$ to TRPV1 through AKAP150.

One major focus of the present study was to determine whether dynamic changes in cellular $\mathrm{PIP}_{2}$ significantly affect AKAP150 association with and sensitization of TRPV1 in the whole-cell environment. Previous reports demonstrate the importance of phosphorylation on TRPV1 activity; namely, through PKA- and PKC-mediated signaling transduction pathways (Premkumar and Ahern, 2000; Bhave et al., 2002, 2003; Bonnington and McNaughton, 2003; Mohapatra and Nau, 2003; Mandadi et al., 2004; Moriyama et al., 2005). Since TRPV1 phosphorylation by these kinases is governed by AKAP150, signaling pathways that control dynamic AKAP150 association with TRPV1 also bear investigation. According to TRPV1 homology structure models, there is a low probability that direct association between the $\mathrm{C}$ terminus of the receptor and $\mathrm{PIP}_{2}$ occurs, due to charge differences among interacting amino acids (Brauchi et al., 2007). Studies on receptor-mediated PLC activation indicate that the effects of $\mathrm{PIP}_{2}$ on TRPV1 are largely indirect in nature (Chuang et al., 2001; Zhang et al., 2005). This concept is demonstrated by Kim et al. (2008), reporting that the membrane protein Pirt1 mediates TRPV1 sensitivity to phosphoinositides in DRG neurons, although recent reports show no FRET between Pirt and TRPV1 in a homologous cell model (Ufret-Vincenty et al., 2011). Together, $\mathrm{PIP}_{2}$ modulation of TRPV1 requires contribution from indirect signaling pathways to yield full effect.

The presence of $\mathrm{PIP}_{2}$ in these studies is as important as the absence of the phosphoinositide. Results from Figures 5 and 6 indicate that the stimulation of PKA in cultured TG neurons results in TRPV1 sensitization. However, the electrophysiological preparation employs whole-cell dialysis, a method that results in the wash-out of $\mathrm{PIP}_{2}$, while the calcium imaging method uses intact cultured neurons. It should be noted that the effect of the wash-out was evident, given that the increase in TRPV1 activation by CAP following whole-cell dialysis was 2.69-fold following PKA activation, compared with 1.70-fold for the intact calcium imaging preparation. The extended wash-out removed available $\mathrm{PIP}_{2}$ from the cell, releasing AKAP150 from its plasma membrane anchorage to associate with and drive PKA phosphorylation of TRPV1. In contrast, the cellular environment tested throughout calcium imaging experiments likely contained resting amounts of $\mathrm{PIP}_{2}$, resulting in the retainment of AKAP150 in the plasma membrane, retarding maximal phosphorylation of TRPV1 by PKA. Importantly, both experimental methods demonstrate PKA sensitization of TRPV1 and identify AKAP150 as the scaffolding molecule that mediates the effects of $\mathrm{PIP}_{2}$ on TRPV1.

In 2008, Zhang and McNaughton reported on a cellpermeable peptide corresponding to amino acids 736-749 of the human TRPV1 C-terminal sequence that was capable of preventing the association of TRPV1 and AKAP79 (human ortholog of AKAP150) in transfected cells. Interestingly, this sequence overlaps with a C-terminal amino acid sequence shared in both TRPV1 and TRPM8 (amino acids 742-753, TRPV1; amino acids 1044-1055, TRPM8). Since both TRPM8 and TRPV1 demonstrate sensitivity to $\mathrm{PIP}_{2}$, it is possible that indirect phosphoinositide effects on these two TRP receptors are driven by their association with AKAP79/150 (Brauchi et al., 2006). Indeed, TRPM8 associates with AKAP79 when overexpressed in an HEK 293 cell model (Zhang et al., 2008). Therefore, it is possible that TRPM8 may also require AKAP150 to be modulated by $\mathrm{PIP}_{2}$.

In Figure 7, the activation of PLC by $\mathrm{m}-3 \mathrm{~m} 3 \mathrm{FBS}$ results in the production of $\mathrm{PIP}_{2}$ degradation products $\mathrm{IP}_{3}$ and DAG, both of which stimulate the activation of PKC (Irvine, 1992; Nishizuka, 1995). Interestingly, in Figure 1 PKC activity in cultured TG were unaffected by $\mathrm{m}-3 \mathrm{~m} 3 \mathrm{FBS}$ and bradykinin treatment conditions that elicited significant PLC activation. Given the data that support a role for PKC in regulating AKAP150 association with the plasma membrane in HEK293 cells (Dell'Acqua et al., 1998), similar results were expected in studies presented herein. Indeed, a previous study using trigeminal neurons found PLC to elicit PKC activation following 15 min of PAR-2 receptor agonist treatment (Patwardhan et al., 2006). However, drug treatments in this study were applied for a shorter time period ( $5 \mathrm{~min}$ ), perhaps not providing the amount of time needed for PLC to stimulate PKC. It is possible, however, that calcium imaging studies presented here detected this increase in PKC activity, revealing increased TRPV1 receptor-mediated calcium accumulation over several minutes following the initial $\mathrm{m}-3 \mathrm{~m} 3 \mathrm{FBS}$ distribution. Importantly, we have provided support for the hypothesis that PLC, and not PKC, provides enough enzymatic activity on its own to stimulate AKAP150 release from the plasma membrane.

In summary, the results presented herein identify AKAP 150 as a mediator of $\mathrm{PIP}_{2}$ effects on TRPV1. Anchorage of the AKAP150 scaffolding protein to $\mathrm{PIP}_{2}$ in the plasma membrane is dissolved following receptor-mediated PLC activation, so that AKAP150 is free to associate with TRPV1 and mediate PKA- and/or PKCdirected phosphorylation and sensitization of the receptor. This previously undescribed mechanism could account for many of the feedforward hyperalgesia symptoms associated with peripheral inflammation.

\section{References}

Bhave G, Zhu W, Wang H, Brasier DJ, Oxford GS, Gereau RW 4th (2002) cAMP-dependent protein kinase regulates desensitization of the capsaicin receptor (VR1) by direct phosphorylation. Neuron 35:721-731.

Bhave G, Hu HJ, Glauner KS, Zhu W, Wang H, Brasier DJ, Oxford GS, Gereau RW 4th (2003) Protein kinase C phosphorylation sensitizes but does not activate the capsaicin receptor transient receptor potential vanilloid 1 (TRPV1). Proc Natl Acad Sci U S A 100:12480-12485.

Bonnington JK, McNaughton PA (2003) Signalling pathways involved in the sensitisation of mouse nociceptive neurones by nerve growth factor. J Physiol 551:433-446.

Bradford MM (1976) A rapid and sensitive method for the quantitation of microgram quantities of protein utilizing the principle of protein-dye binding. Anal Biochem 72:248-254.

Brauchi S, Orta G, Salazar M, Rosenmann E, Latorre R (2006) A hot-sensing cold receptor: C-terminal domain determines thermosensation in transient receptor potential channels. J Neurosci 26:4835-4840.

Brauchi S, Orta G, Mascayano C, Salazar M, Raddatz N, Urbina H, Rosen- 
mann E, Gonzalez-Nilo F, Latorre R (2007) Dissection of the components for PIP2 activation and thermosensation in TRP channels. Proc Natl Acad Sci U S A 104:10246-10251.

Carr DW, Stofko-Hahn RE, Fraser ID, Bishop SM, Acott TS, Brennan RG, Scott JD (1991) Interaction of the regulatory subunit (RII) of cAMPdependent protein kinase with RII-anchoring proteins occurs through an amphipathic helix binding motif. J Biol Chem 266:14188-14192.

Caterina MJ, Schumacher MA, Tominaga M, Rosen TA, Levine JD, Julius D (1997) The capsaicin receptor: a heat-activated ion channel in the pain pathway. Nature 389:816-824.

Cesare P, Moriondo A, Vellani V, McNaughton PA (1999) Ion channels gated by heat. Proc Natl Acad Sci U S A 96:7658-7663.

Chuang HH, Prescott ED, Kong H, Shields S, Jordt SE, Basbaum AI, Chao MV, Julius D (2001) Bradykinin and nerve growth factor release the capsaicin receptor from PtdIns(4,5)P2-mediated inhibition. Nature 411:957-962.

Coghlan VM, Perrino BA, Howard M, Langeberg LK, Hicks JB, Gallatin WM, Scott JD (1995) Association of protein kinase A and protein phosphatase 2B with a common anchoring protein. Science 267:108-111.

Dell'Acqua ML, Scott JD (1997) Protein kinase A anchoring. J Biol Chem 272:12881-12884

Dell'Acqua ML, Faux MC, Thorburn J, Thorburn A, Scott JD (1998) Membrane-targeting sequences on AKAP79 bind phosphatidylinositol-4, 5-bisphosphate. EMBO J 17:2246-2260.

Hirose K, Kadowaki S, Tanabe M, Takeshima H, Iino M (1999) Spatiotemporal dynamics of inositol 1,4,5-trisphosphate that underlies complex Ca2+ mobilization patterns. Science 284:1527-1530.

Irvine RF (1992) Inositol lipids in cell signalling. Curr Opin Cell Biol 4:212-219.

Jeske NA, Patwardhan, AM, Gamper N, Price TJ, Akopian AN, Hargreaves KM (2006) Cannabinoid WIN 55,212-2 regulates TRPV1 phosphorylation in sensory neurons. J Biol Chem 281:32879-32890.

Jeske NA, Diogenes A, Ruparel NB, Fehrenbacher JC, Henry M, Akopian AN, Hargreaves KM (2008) A-kinase anchoring protein mediates TRPV1 thermal hyperalgesia through PKA phosphorylation of TRPV1. Pain 138:604-616.

Jeske NA, Patwardhan AM, Ruparel NB, Akopian AN, Shapiro MS, Henry MA (2009) A-kinase anchoring protein 150 controls protein kinase C-mediated phosphorylation and sensitization of TRPV1. Pain 146:301-307.

Jung J, Shin JS, Lee SY, Hwang SW, Koo J, Cho H, Oh U (2004) Phosphorylation of vanilloid receptor 1 by Ca2+/calmodulin-dependent kinase II regulates its vanilloid binding. J Biol Chem 279:7048-7054.

Kim AY, Tang Z, Liu Q, Patel KN, Maag D, Geng Y, Dong X (2008) Pirt, a phosphoinositide-binding protein, functions as a regulatory subunit of TRPV1. Cell 133:475-485.

Klauck TM, Faux MC, Labudda K, Langeberg LK, Jaken S, Scott JD (1996) Coordination of three signaling enzymes by AKAP79, a mammalian scaffold protein. Science 271:1589-1592.

Kobayashi K, Fukuoka T, Obata K, Yamanaka H, Dai Y, Tokunaga A, Noguchi K (2005) Distinct expression of TRPM8, TRPA1, and TRPV1 mRNAs in rat primary afferent neurons with adelta/c-fibers and colocalization with trk receptors. J Comp Neurol 493:596-606.

Kunzelmann K, Bachhuber T, Regeer R, Markovich D, Sun J, Schreiber R (2005) Purinergic inhibition of the epithelial $\mathrm{Na}+$ transport via hydrolysis of PIP2. FASEB J 19:142-143.

Li Y, Gamper N, Hilgemann DW, Shapiro MS (2005) Regulation of Kv7 (KCNQ) $\mathrm{K}+$ channel open probability by phosphatidylinositol 4,5bisphosphate. J Neurosci 25:9825-9835.

Liu B, Zhang C, Qin F (2005) Functional recovery from desensitization of vanilloid receptor TRPV1 requires resynthesis of phosphatidylinosidol 4,5-bisphosphate. J Neurosci 25:4835-4843.

Logothetis DE, Petrou VI, Adney SK, Mahajan R (2010) Channelopathies linked to plasma membrane phosphoinositides. Pflugers Arch 460:321-341.

Lukacs V, Thyagarajan B, Varnai P, Balla A, Balla T, Rohacs T (2007) Dual regulation of TRPV1 by phosphoinositides. J Neurosci 27:7070-7080.

Mandadi S, Numazaki M, Tominaga M, Bhat MB, Armati PJ, Roufogalis BD (2004) Activation of protein kinase C reverses capsaicin-induced calcium-dependent desensitization of TRPV1 ion channels. Cell Calcium 35:471-478
Mo G, Bernier LP, Zhao Q, Chabot-Doré AJ, Ase AR, Logothetis D, Cao CQ, Séguéla P (2009) Subtype-specific regulation of P2X3 and P2X2/3 receptors by phosphoinositides in peripheral nociceptors. Mol Pain 5:47.

Mohapatra DP, Nau C (2003) Desensitization of capsaicin-activated currents in the vanilloid receptor TRPV1 is decreased by the cyclic AMPdependent protein kinase pathway. J Biol Chem 278:50080-50090.

Mohapatra DP, Nau C (2005) Regulation of Ca2+-dependent desensitization in the vanilloid receptor TRPV1 by calcineurin and cAMPdependent protein kinase. J Biol Chem 280:13424-13432.

Moriyama T, Higashi T, Togashi K, Iida T, Segi E, Sugimoto Y, Tominaga T, Narumiya S, Tominaga M (2005) Sensitization of TRPV1 by EP1 and IP reveals peripheral nociceptive mechanism of prostaglandins. Mol Pain $1: 3$.

Nishizuka Y (1995) Protein kinase C and lipid signaling for sustained cellular responses. FASEB J 9:484-496.

Patwardhan AM, Diogenes A, Berg KA, Fehrenbacher JC, Clarke WP, Akopian AN, Hargreaves KM (2006) PAR-2 agonists activate trigeminal nociceptors and induce functional competence in the delta opioid receptor. Pain 125:114-124.

Patwardhan AM, Akopian AN, Ruparel NB, Diogenes A, Weintraub ST, Uhlson C, Murphy RC, Hargreaves KM (2010) Heat generates oxidized linoleic acid metabolites that activate TRPV1 and produce pain in rodents. J Clin Invest 120:1617-1626.

Por ED, Samelson BK, Belugin S, Akopian AN, Scott JD, Jeske NA (2010) $\mathrm{PP} 2 \mathrm{~B} /$ calcineurin-mediated desensitization of TRPV1 channels does not require AKAP150. Biochem J 432:549-556.

Premkumar LS, Ahern GP (2000) Induction of vanilloid receptor channel activity by protein kinase C. Nature 408:985-990.

Prescott ED, Julius D (2003) A modular PIP2 binding site as a determinant of capsaicin receptor sensitivity. Science 300:1284-1288.

Price TJ, Patwardhan A, Akopian AN, Hargreaves KM, Flores CM (2004) Modulation of trigeminal sensory neuron activity by the dual cannabinoid-vanilloid agonists anandamide, $\mathrm{N}$-arachidonoyl-dopamine and arachidonyl-2-chloroethylamide. Br J Pharmacol 141:1118-1130.

Rathee PK, Distler C, Obreja O, Neuhuber W, Wang GK, Wang SY, Nau C, Kress M (2002) PKA/AKAP/VR-1 module: a common link of Gsmediated signaling to thermal hyperalgesia. J Neurosci 22:4740-4745.

Ross RA, Gibson TM, Brockie HC, Leslie M, Pashmi G, Craib SJ, Di Marzo V, Pertwee RG (2001) Structure-activity relationship for the endogenous cannabinoid, anandamide, and certain of its analogues at vanilloid receptors in transfected cells and vas deferens. Br J Pharmacol 132:631-640.

Rowan MP, Berg KA, Milam SB, Jeske NA, Roberts JL, Hargreaves KM, Clarke WP (2010) 17beta-estradiol rapidly enhances bradykinin signaling in primary sensory neurons in vitro and in vivo. J Pharmacol Exp Ther 335:190-196.

Schmidt M, Dubin AE, Petrus MJ, Earley TJ, Patapoutian A (2009) Nociceptive signals induce trafficking of TRPA1 to the plasma membrane. Neuron 64:498-509.

Schnizler K, Shutov LP, Van Kanegan MJ, Merrill MA, Nichols B, McKnight GS, Strack S, Hell JW, Usachev YM (2008) Protein kinase A anchoring via AKAP150 is essential for TRPV1 modulation by forskolin and prostaglandin E2 in mouse sensory neurons. J Neurosci 28:4904-4917.

Stein AT, Ufret-Vincenty CA, Hua L, Santana LF, Gordon SE (2006) Phosphoinositide 3-kinase binds to TRPV1 and mediates NGF-stimulated TRPV1 trafficking to the plasma membrane. J Gen Physiol 128:509-522.

Tominaga M, Caterina MJ, Malmberg AB, Rosen TA, Gilbert H, Skinner K, Raumann BE, Basbaum AI, Julius D (1998) The cloned capsaicin receptor integrates multiple pain-producing stimuli. Neuron 21:531-543.

Tunquist BJ, Hoshi N, Guire ES, Zhang F, Mullendorff K, Langeberg LK, Raber J, Scott JD (2008) Loss of AKAP150 perturbs distinct neuronal processes in mice. Proc Natl Acad Sci U S A 105:12557-12562.

Ufret-Vincenty CA, Klein RM, Hua L, Angueyra J, Gordon SE (2011) Localization of the PIP2 sensor of TRPV1 ion channels. J Biol Chem 286:9688-9698.

Zhang X, Huang J, McNaughton PA (2005) NGF rapidly increases membrane expression of TRPV1 heat-gated ion channels. EMBO J 24:4211-4223.

Zhang X, Li L, McNaughton PA (2008) Proinflammatory mediators modulate the heat-activated ion channel TRPV1 via the scaffolding protein AKAP79/150. Neuron 59:450-461. 